\section{Identification of the Appropriate Leaf Sampling Period for Nutrient Analysis in 'Hass' Avocado}

\author{
Samuel Salazar-García ${ }^{2}$ and Isidro J.L. González-Durán \\ Instituto Nacional de Investigaciones Forestales, Agricolas y Pecuarias, \\ Campo Experimental Santiago Ixcuintla. Apdo. Postal 100, Santiago \\ Ixcuintla, Nayarit 63300, Mexico
}

\section{Martha E. Ibarra-Estrada ${ }^{1}$ \\ Santiago Ixcuintla, Nayarit, Mexico}

Additional index words. Persea americana, plant nutrition, nutrient resorption, mathematical derivatives

\begin{abstract}
This research was carried out from 2004 to 2005 in two commercial 'Hass' avocado orchards cultivated under rainfed conditions in a hot subhumid climate of the state of Nayarit, Mexico. The objectives of this study were to: 1) establish the patterns in nutrient concentrations during the lifespan of winter and summer vegetative flush leaves; and 2) validate a methodology based on mathematical functions to identify the appropriate period for leaf sampling to diagnose plant nutrition in avocado considering its two major vegetative flushes. Leaf samples were taken monthly for each vegetative flush, starting when leaf length was $5 \mathrm{~cm}$ or greater and concluding at leaf abscission. Starting at vegetative budbreak, winter and summer leaves lived 12.5 and 7.8 months, respectively. Summer flush leaves grew faster and attained greater length than winter leaves. A mathematical model based on the concentration of macro- and micronutrients through the lifespan of avocado leaves was evaluated. This model was used to determine the period when nutrient concentrations became stable and, consequently, to identify the proper leaf sampling period. For the 'Hass' avocado in Nayarit, the period for sampling winter flush leaves corresponded to 6.6- to 7.9-month-old leaves (4 Sept. to 13 Oct.). For summer leaves the optimum period was shorter and occurred when leaves were 3.9 to 4.9 months old ( 5 Dec. to 5 Jan.). The procedure and sampling time obtained here should be tested in other regions.
\end{abstract}

Leaf analysis is an important tool for proper nutrition management in avocado orchards. It serves for diagnosis of deficiencies, excesses, or nutritional imbalances. It is also useful for making fertilizer recommendations and monitoring the response of trees to fertilizer applications (Salazar-García, 2002). In most commercial avocado orchards, 4- to 7-month-old leaves are sampled for nutrient analyses (Crowley et al., 1993; Dixon et al., 2007; Maldonado-Torres et al., 2007; Salazar-García, 2002).

Two criteria have been established to sample avocado leaves for nutrient analyses: 1) leaves must be fully expanded; and 2)

\footnotetext{
Received for publication 29 Aug. 2014. Accepted for publication 27 Oct. 2014

This investigation was partially funded by INIFAP, the Consejo Nacional de Ciencia y Tecnología (CONACYT), the FOMIX- Nayarit, and the Fundación Produce Nayarit.

We express our appreciation to Alberto Ante and Juan Nájera for allowing the use of their avocado orchards as well as Luis E. Cossio-Vargas and José González-Valdivia for their technical support. Special thanks to Dr. Ricardo Goenaga for reading the manuscript.

${ }^{1}$ Independent Researcher.

${ }^{2}$ To whom reprint requests should be addressed; e-mail samuelsalazar@prodigy.net.mx.
}

nutrient concentrations must be stable. The second criterion is usually met by determining nutrient concentrations and visually detecting the stabilization period. The disadvantage of using the visual criterion is not having an exact date for the beginning and end of the stabilization period, because only data corresponding to each of the sampling dates are known. Besides this, estimating nutrient concentration in the leaves between sampling dates is not exact; therefore, determining the period of stabilization is subjective. An additional problem is that the units used to present the various nutrient concentrations on a graph are different (i.e., $\%$ or $\left.\mathrm{mg} \cdot \mathrm{kg}^{-1}\right)$; therefore, the variations in performance of all the nutrients on one single graph cannot be accurately appreciated.

In the state of Nayarit, 'Hass' avocado is cultivated without irrigation (rainfed) and produces two vegetative flushes. The winter flush occurs in January to February and is the most important because it produces the largest proportion of floral buds in next year's flowering; in addition, it supports fruit development until maturity. The summer flush occurs during the rainy season (July to August) and is of intermediate importance for flowering (Cossio-Vargas et al., 2008). In Nayarit, 'Hass' avocado presents only one flowering flush during the winter and a single harvest period in October to December of the same year (Salazar-García et al., 2007a).

The lifespan of avocado leaves may differ depending on the vegetative flush of origin and the demand for nutrients and other compounds in critical phases of tree phenology as well as stresses that cause or accelerate their abscission (Liu et al., 1999; Roets et al., 2006). A 10- to 12-month life expectancy is mentioned for 'Hass' avocado leaves (Whiley and Schaffer, 1994), although in Nayarit, winter and summer flush 'Hass' leaves live 12 and 9 months, respectively (Salazar-García et al., 2007b).

This research was undertaken to determine or validate the leaf sampling period currently used for 'Hass' avocado in Nayarit and had the following objectives: 1) to establish the patterns in nutrient concentrations during the lifetime of winter and summer vegetative flush leaves; and 2) to validate a methodology to identify the appropriate leaf sampling period for nutritional diagnosis considering its two major vegetative flushes.

\section{Materials and Methods}

Plant material. Two rainfed commercial orchards of 'Hass' avocado grafted to local West Indian seedling rootstocks were studied in 2004-05. Orchards were on a Chromic Cambisol medium texture soil (INEGI, 1999) in the hot subhumid climate of the municipality of Tepic, Nayarit (García-Amaro, 1998). The "Nájera" orchard was located in La Yerba (lat. $21^{\circ} 31.6^{\prime} \mathrm{N}$, long. $105^{\circ} 02.9^{\prime} \mathrm{W}$ ) at $858 \mathrm{~m}$ above sea level (asl). The "Ante" orchard was situated in Venustiano Carranza (lat. $21^{\circ} 32.0^{\prime} \mathrm{N}$, long. $104^{\circ} 59.1^{\prime} \mathrm{W}$ ) at $927 \mathrm{~m}$ asl. In both orchards average mean annual rainfall was $1225 \mathrm{~mm}$, which occurred from June to September. At the beginning of the study, trees were 10 years old and established at a spacing of $8 \times 8 \mathrm{~m}$.

Orchards received growers' standard management practices using a site-specific fertilization program (Salazar-García et al., 2009; Salazar-García and Lazcano-Ferrat, 2003). The fertilization program was slightly modified every year according to yield, soil, and leaf analysis. However, in the 2 years before this study, the following nutrient amounts per tree were applied to the soil each year: $2.14 \mathrm{~kg}$ nitrogen $(\mathrm{N})$ (ammonium sulphate $20.5 \% \mathrm{~N}$ and urea $46 \% \mathrm{~N}), 0.324 \mathrm{~kg}$ phosphorus (P) (diammonium phosphate $\left.18 \% \mathrm{~N}, 46 \% \mathrm{P}_{2} \mathrm{O}_{5}\right), 2.10 \mathrm{~kg}$ potassium $(\mathrm{K})$ (potassium sulphate $50 \% \mathrm{~K}_{2} \mathrm{O}$ ), $0.061 \mathrm{~kg}$ magnesium $(\mathrm{Mg})\left(\mathrm{K}-\mathrm{MAG} 22 \% \mathrm{~K}_{2} \mathrm{O}, 18 \%\right.$ $\mathrm{MgO}, 22 \% \mathrm{SO}_{4}$ ), $0.810 \mathrm{~kg}$ zinc ( $\mathrm{Zn}$ ) (zinc sulphate $36 \% \mathrm{Zn}$ ), and $30.2 \mathrm{~g}$ boron (B) (Boronat $32 \% \mathrm{~B}_{2} \mathrm{O}_{3}$ ). Except $\mathrm{N}$, fertilizers were applied by hand in solid form around each tree in a 20 -cm-deep $\times 30$-cm-wide trench at 1.5 to $2 \mathrm{~m}$ away from the trunk. Nitrogen was applied by hand to the soil canopy shadow area and split in three applications (July, August, and September). All the $\mathrm{P}$ and $\mathrm{Mg}$ were applied in July; the rest of nutrients were split in two applications (July and September). 
Soil sampling. From each orchard, a mixed soil sample was obtained from five of the 10 trees previously selected at a $0-$ to $30-\mathrm{cm}$ depth. In Apr. 2005, two subsamples were taken from each tree with a stainless steel auger. A subsample was taken halfway between the tree's trunk and the dripline zone, and the other one from the drip line zone. Texture, $\mathrm{pH}\left(1: 2 \mathrm{H}_{2} \mathrm{O}\right)$, electrical conductivity, organic matter, N-inorganic, P-Bray, K, calcium $(\mathrm{Ca}), \mathrm{Mg}$, sodium $(\mathrm{Na})$, iron $(\mathrm{Fe})$, $\mathrm{Zn}$, copper $(\mathrm{Cu})$, manganese $(\mathrm{Mn})$, and $\mathrm{B}$ were determined in a commercial laboratory under The North American Proficiency Testing Program of the Soil Science Society of America.

Leaf sampling. In each orchard, trees with historical yields $100 \mathrm{~kg}$ or greater were identified. From this population, 10 trees were randomly chosen and in each tree, a cohort of 300 winter and 300 summer proleptic vegetative shoots was tagged at the time of budbreak. This corresponded to the zero time for winter (19 Feb. 2004) and summer (11 Aug. 2004) vegetative shoots. From these dates onward, days after budbreak (DABB) were counted up to the date of leaf abscission.

Leaf samples were collected monthly alternating between odd and even numbered trees (five trees per sampling date) and began when the leaves reached $5 \mathrm{~cm}$ or greater in length and finished at leaf abscission. At each sampling date, 20 healthy, fully expanded leaves (leaf blade + petiole), situated in basipetal positions 6 and 7, were collected per tree.

A total of 12 leaf samples for winter (Apr. 2004 to Mar. 2005) and eight for summer (Sept. 2004 to Apr. 2005) vegetative flushes were collected within the first week of each month. At each sampling time, the length of 10 leaves (blade) per tree per orchard was measured. Leaves were washed and dehydrated in a Laboratory-line Imperial-5 digital forced-air oven (3488M USA) at $70{ }^{\circ} \mathrm{C}$, until constant weight; subsequently, the samples were ground in a Thomas Scientific (Wiley Mini Mill 3383-L10) stainless steel mill with a 40-caliber mesh and analyzed for N, P, K, $\mathrm{Ca}, \mathrm{Mg}$, sulfur (S), Fe, Cu, Mn, Zn, and B in a commercial laboratory accredited by The North American Proficiency Testing Program of the Soil Science Society of America.
Appropriate leaf sampling period. Mathematical functions were generated using $\mathrm{DABB}$ as the independent variable and the concentrations of each nutrient as dependent variables. The general equation was:

$$
\begin{aligned}
\text { Nutrient }= & \beta_{0}+\beta_{1} D+\beta_{2} D^{2}+\beta_{3} D^{3} \\
& +\beta_{4} D^{4}+\beta_{5} D^{5} ;
\end{aligned}
$$

where $\mathrm{D}=$ days after budbreak and $\beta=$ mathematical coefficients

Afterward, the best mathematical function according to its order of response (second to fifth order) for each nutrient was selected using the Stepwise procedure (SAS, 2009). The criteria for choosing the best functions were: 1 ) value of $R^{2} ; 2$ ) a small mean square error; and 3) the value of $\mathrm{Cp}$ (Draper and Smith, 1981; Neter et al., 1985). Once the best mathematical functions were identified, their mathematical coefficients $\left(\beta_{0}, \ldots \ldots \beta_{n}\right)$ were calculated by the REG procedure, according to the aforementioned criteria. Predicted values for each day of nutrient evolution were obtained by replacing the value of DABB in the general equation and plotted in the SigmaPlot 10 program (Systat Software Inc., Chicago, IL).

Mathematical derivatives were calculated for each day of the best nutrient concentration mathematical functions. Values of derivatives can be positive or negative. As far as these values approach zero, the rate of change for each nutrient concentration is lower.

To identify the periods of nutrient concentration variation and stability, showing the adequate leaf sampling period, the values of the mathematical function derivative of every nutrient were plotted in SigmaPlot (2006). The criterion used for determining the best leaf sampling period was that the derivative of the best mathematical functions of each nutrient was equal or close to zero (Granville et al., 1963). With these results, a table was made to show the periods of nutrient stability for macro- and micronutrients as well as the appropriate leaf sampling dates for each vegetative flush.

Data analysis. Data from both orchards were combined and quality control was performed by using the Boxplot procedure of the MINITAB program (Minitab Inc.,

Table 1. Soil characteristics (Apr. 2005) at 0- to 30-cm depth in the two avocado orchards included in the

\begin{tabular}{|c|c|c|}
\hline Characteristic & Ante orchard & Nájera orchard \\
\hline$\overline{\mathrm{pH}\left(1: 2 \mathrm{H}_{2} \mathrm{O}\right)}$ & 5.85 (moderate acid) & $4.76 \mathrm{~b}$ (very acid) \\
\hline Organic matter $(\%)$ & $5.30(\mathrm{VH})$ & $5.71(\mathrm{VH})$ \\
\hline \multicolumn{3}{|c|}{$\mathrm{mg} \cdot \mathrm{kg}^{-1}$} \\
\hline $\mathrm{N}-\mathrm{NO}_{3}$ & $72.39(\mathrm{~N})$ & $80.79(\mathrm{~N})$ \\
\hline P-Bray & $13.7(\mathrm{MoL})$ & $7.01(\mathrm{~L})$ \\
\hline Potassium & $805.4(\mathrm{H})$ & $672.9(\mathrm{H})$ \\
\hline Calcium & $903.2(\mathrm{MoL})$ & $1077.5(\mathrm{MoL})$ \\
\hline Magnesium & $153.65(\mathrm{MoL})$ & $128.87(\mathrm{MoL})$ \\
\hline Sodium & $19.92(\mathrm{VL})$ & 20.32 (VL) \\
\hline Iron & $23.85(\mathrm{MoH})$ & $18.50(\mathrm{MoH})$ \\
\hline Zinc & $10.32(\mathrm{VH})$ & $19.80(\mathrm{VH})$ \\
\hline Manganese & $17.12(\mathrm{MoH})$ & $36.66(\mathrm{H})$ \\
\hline Copper & $2.01(\mathrm{H})$ & $0.53(\mathrm{MoL})$ \\
\hline Boron & $1.06(\mathrm{MoL})$ & $1.36(\mathrm{M})$ \\
\hline
\end{tabular}
study.

Laboratory interpretation: $\mathrm{H}=$ high; $\mathrm{MoH}=$ moderately high; $\mathrm{VA}=$ very high; $\mathrm{M}=$ medium; $\mathrm{L}=$ low; $\mathrm{MoL}=$ moderately low; $\mathrm{VL}=$ very low; $\mathrm{N}=$ normal.
1996). For leaf length, a completely randomized design with 20 tree replicates per vegetative flush was used. Means comparison was done by the Waller-Duncan test $(P=0.05)$.

\section{Results}

Soil fertility. There were few differences in soil fertility between the two 'Hass' avocado orchards. Organic matter was high in both chards. The Nájera orchard had a more acidic $\mathrm{pH}$ and higher concentrations of $\mathrm{Mn}$ and $\mathrm{B}$ than the Ante orchard. The other nutrients were at similar concentrations (Table 1).

Leaf growth. Leaves of winter vegetative flush reached $5 \mathrm{~cm}$ or greater in length by April $(5.2 \mathrm{~cm})$ and summer leaves did so by September $(5.8 \mathrm{~cm})$. Full leaf expansion was observed by October (winter flush) and February (summer flush). Final length was greater $(P=0001)$ for summer $(19 \mathrm{~cm})$ than for winter $(17.3 \mathrm{~cm})$ leaves (data not shown). From budbreak to leaf abscission, leaves of winter and summer flushes lived 12.5 and 7.8 months, respectively.

\section{Nutrient concentrations throughout the leaf growth cycle}

Nitrogen. Leaf $\mathrm{N}$ concentrations were different between vegetative flushes. In winter leaves, the initial concentration was lower $\left(17.4 \mathrm{~g} \cdot \mathrm{kg}^{-1}\right)$ than in the summer leaves $\left(24.1 \mathrm{~g} \cdot \mathrm{kg}^{-1}\right)$. Differences continued through leaf life and maximum concentrations for winter $\left(21.4 \mathrm{~g} \cdot \mathrm{kg}^{-1}\right)$ and summer $\left(24.9 \mathrm{~g} \cdot \mathrm{kg}^{-1}\right)$ leaves were reached 194 to 225 and 42 DABB, respectively (Fig. 1).

Phosphorus. Initial $\mathrm{P}$ concentration was higher in summer $\left(1.8 \mathrm{~g} \cdot \mathrm{kg}^{-1}\right)$ than in winter leaves $\left(1.5 \mathrm{~g} \cdot \mathrm{kg}^{-1}\right)$. After this stage, winter leaves showed a decline in $\mathrm{P}$ concentrations until leaf abscission $\left(0.8 \mathrm{~g} \cdot \mathrm{kg}^{-1}\right)$. For summer leaves, a decrease $\left(1.4 \mathrm{~g} \cdot \mathrm{kg}^{-1} ; 105 \mathrm{DABB}\right)$ or an increase $\left(1.5 \mathrm{~g} \cdot \mathrm{kg}^{-1} ; 164 \mathrm{DABB}\right)$ in $\mathrm{P}$ concentration was observed, ending with 1.2 $\mathrm{g} \cdot \mathrm{kg}^{-1}$ at abscission time (Fig. 1).

Potassium. Initial $\mathrm{K}$ concentrations were higher in winter $\left(11.9 \mathrm{~g} \cdot \mathrm{kg}^{-1}\right)$ than in summer (10.2 $\left.\mathrm{g} \cdot \mathrm{kg}^{-1}\right)$ leaves. Afterward, there was a slight increase in $\mathrm{K}$ concentrations at 294 DABB (winter leaves) and 112 DABB (summer leaves). At abscission date, summer leaves had a higher $\mathrm{K}$ concentration (7.0 $\left.\mathrm{g} \cdot \mathrm{kg}^{-1}\right)$ than winter leaves $\left(4.5 \mathrm{~g} \cdot \mathrm{kg}^{-1}\right)$ (Fig. 1).

Calcium. The pattern of changes in $\mathrm{Ca}$ concentrations in leaves of the two vegetative flushes was very similar, increasing with leaf age. Initial values were higher in summer $\left(9.0 \mathrm{~g} \cdot \mathrm{kg}^{-1}\right)$ than in winter $\left(6.0 \mathrm{~g} \cdot \mathrm{kg}^{-1}\right)$ leaves. However, at abscission date, these differences went to a minimum (23.2 $\mathrm{g} \cdot \mathrm{kg}^{-1}$ and 24.5 $\mathrm{g} \cdot \mathrm{kg}^{-1}$ for summer and winter leaves) (Fig. 1).

Magnesium. Changes in $\mathrm{Mg}$ concentrations for leaves of both vegetative flushes were comparable to $\mathrm{Ca}$ and increased with leaf age. Initial and final concentrations for winter and summer leaves were $2.6 \mathrm{~g} \cdot \mathrm{kg}^{-1}$ and $6.8 \mathrm{~g} \cdot \mathrm{kg}^{-1}$, and $3.2 \mathrm{~g} \cdot \mathrm{kg}^{-1}$ and $6.3 \mathrm{~g} \cdot \mathrm{kg}^{-1}$, respectively (Fig. 1).

Sulfur. Leaves of the two vegetative flushes showed different patterns for $\mathrm{S}$ 

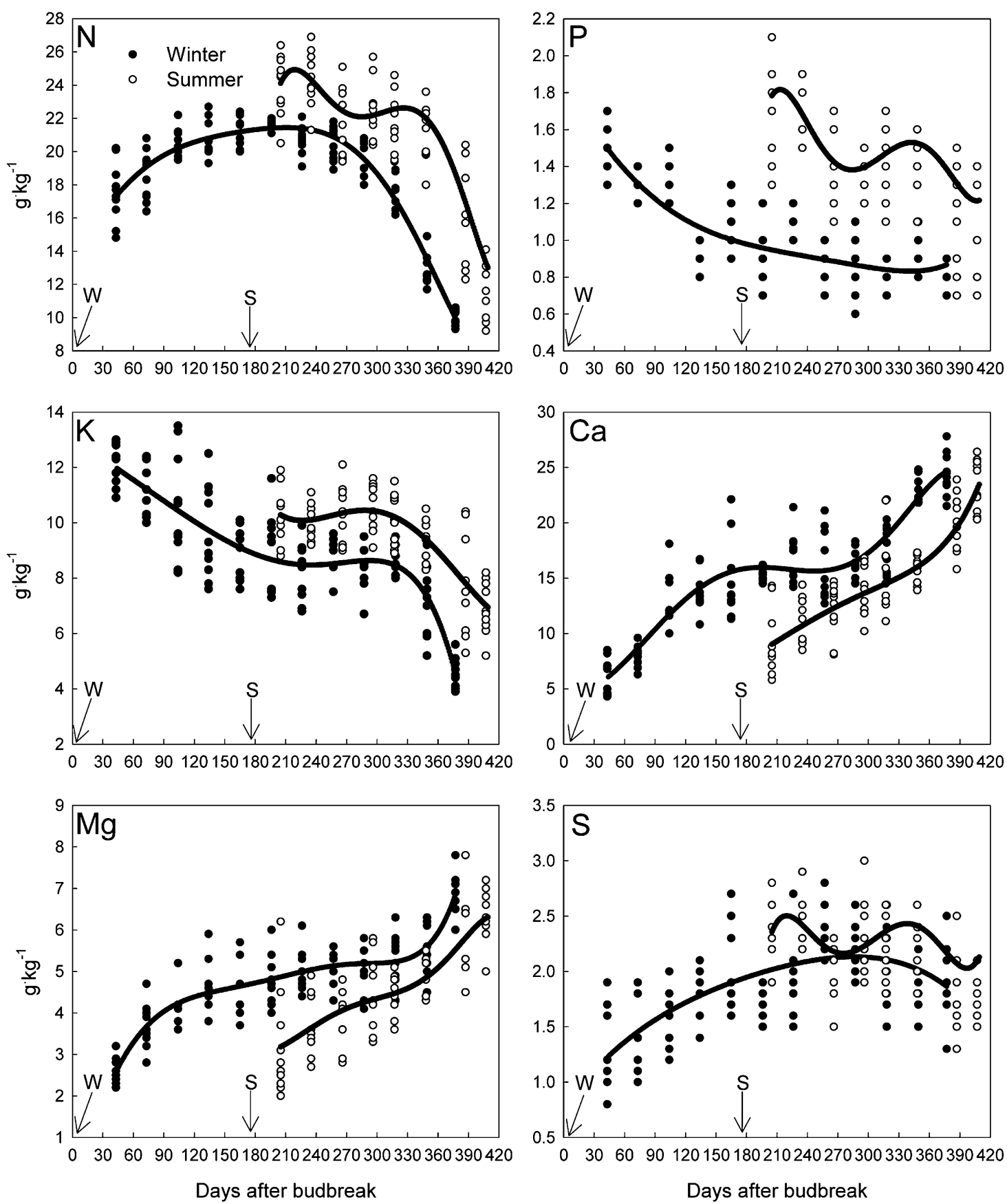

Fig. 1. Effect of leaf age on macronutrient concentrations ( $\mathrm{g} \cdot \mathrm{kg}^{-1} \mathrm{dry}$ weight) of winter and summer vegetative flushes of 'Hass' avocado (data are a pool of Nájera and Ante orchards). Solid lines are predicted concentrations. Arrows point to budbreak date [Winter (W): 19 Feb. 2004; Summer (S): 11 Aug. 2004]. To calculate DABB for summer leaves, subtract $175 \mathrm{~d}$. DABB = days after budbreak.

concentrations. In winter leaves, the initial $\mathrm{S}$ concentration was lower $\left(1.2 \mathrm{~g} \cdot \mathrm{kg}^{-1}\right)$ than for summer leaves $\left(2.3 \mathrm{~g} \cdot \mathrm{kg}^{-1}\right)$, then peaked $(2.1$ $\mathrm{g} \cdot \mathrm{kg}^{-1}$ ) at $\approx 275 \mathrm{DABB}$ and declined to 1.9 $\mathrm{g} \cdot \mathrm{kg}^{-1}$ at abscission. The $\mathrm{S}$ concentration in summer leaves exhibited two peaks, one at 43 $\operatorname{DABB}\left(2.5 \mathrm{~g} \cdot \mathrm{kg}^{-1}\right)$ and another at $161 \mathrm{DABB}$ (2.4 g. $\left.\mathrm{kg}^{-1}\right)$ (Fig. 1).

Iron. Fe concentrations were different between winter and summer leaves. Winter leaves started at $41.6 \mathrm{mg} \cdot \mathrm{kg}^{-1}$, increased with leaf age to $85.7 \mathrm{mg} \cdot \mathrm{kg}^{-1}$ at $349 \mathrm{DABB}$, and then had a small decrease to 83.2 $\mathrm{mg} \cdot \mathrm{kg}^{-1}$ at abscission date. Fe concentration in summer leaves started slightly lower (36 $\mathrm{mg} \cdot \mathrm{kg}^{-1}$ ) than the winter leaves and had a small decrease to later reach its maximum (131 $\left.\mathrm{mg} \cdot \mathrm{kg}^{-1}\right) 167 \mathrm{DABB}$. At abscission date (233 DABB), Fe concentration was $91.6 \mathrm{mg} \cdot \mathrm{kg}^{-1}$ (Fig. 2).

Copper. Leaves of the two vegetative flushes showed different patterns for $\mathrm{Cu}$ concentrations. In winter leaves, initial $\mathrm{Cu}$ concentration was $7.1 \mathrm{mg} \cdot \mathrm{kg}^{-1}$ then increased to $40.5 \mathrm{mg} \cdot \mathrm{kg}^{-1}$ at $162 \mathrm{DABB}$, peaked $(55.7$ $\mathrm{mg} \cdot \mathrm{kg}^{-1}$ ) at $346 \mathrm{DABB}$, and decreased to 46.6 $\mathrm{mg} \cdot \mathrm{kg}^{-1}$ at abscission date. As for summer leaves, initial concentration was $20 \mathrm{mg} \cdot \mathrm{kg}^{-1}$, then peaked $\left(83 \mathrm{mg} \cdot \mathrm{kg}^{-1}\right)$ at $\approx 171 \mathrm{DABB}$, and thereafter declined to $27.7 \mathrm{mg} \cdot \mathrm{kg}^{-1}$ at abscission time (Fig. 2).

Manganese. In winter leaves, initial Mn concentration was $86 \mathrm{mg} \cdot \mathrm{kg}^{-1}$ followed by a constant increase to reach a maximum of $477 \mathrm{mg} \cdot \mathrm{kg}^{-1}$ at the time of abscission. A contrasting pattern occurred for summer leaves, which started at $192 \mathrm{mg} \cdot \mathrm{kg}^{-1}$ and peaked at $172 \mathrm{DABB}\left(959 \mathrm{mg} \cdot \mathrm{kg}^{-1}\right)$ to later decline to $529 \mathrm{mg} \cdot \mathrm{kg}^{-1}$ at abscission date (Fig. 2).

Zinc. Pattern of $\mathrm{Zn}$ concentration showed almost no change in winter leaves. It varied 

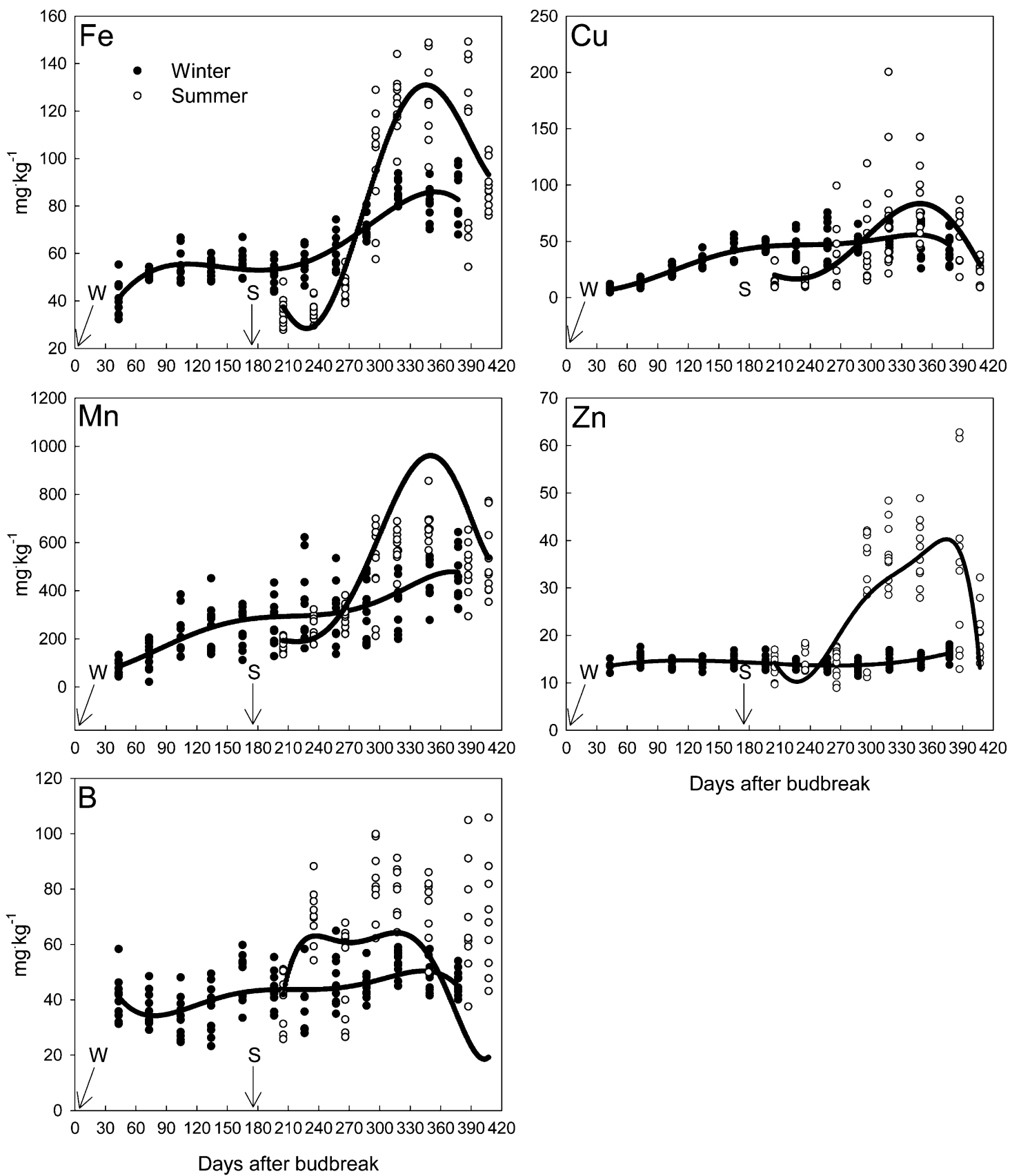

Days after budbreak

Fig. 2. Effect of leaf age on micronutrient concentrations $\left(\mathrm{mg} \cdot \mathrm{kg}^{-1}\right.$ dry weight) of winter and summer vegetative flushes of 'Hass' avocado (data are a pool of Nájera and Ante orchards). Solid lines are predicted concentrations. Arrows point to budbreak date [Winter (W): 19 Feb. 2004; Summer (S): 11 Aug. 2004]. To calculate DABB for summer leaves, subtract $175 \mathrm{~d}$. DABB = days after budbreak.

from $13.6 \mathrm{mg} \cdot \mathrm{kg}^{-1}$ (initial value) to $16.1 \mathrm{mg} \cdot \mathrm{kg}^{-1}$ (abscission date). Summer leaves had higher values than winter leaves. Zinc started at $14.3 \mathrm{mg} \cdot \mathrm{kg}^{-1}$ and reached $40.2 \mathrm{mg} \cdot \mathrm{kg}^{-1}$ at $197 \mathrm{DABB}$ to further decrease to $8.3 \mathrm{mg} \cdot \mathrm{kg}^{-1}$ (abscission date) (Fig. 2).

Boron. Winter leaves showed little changes from first sampling date (40.6 $\mathrm{mg} \cdot \mathrm{kg}^{-1}$ ) through leaf abscission (45.2 $\left.\mathrm{mg} \cdot \mathrm{kg}^{-1}\right)$. Summer leaves had a different pattern; initial value was $42.2 \mathrm{mg} \cdot \mathrm{kg}^{-1}$, which increased at 57 DABB to concentrations between 62.8 and $64.0 \mathrm{mg} \cdot \mathrm{kg}^{-1}$ and then declined to $19.2 \mathrm{mg} \cdot \mathrm{kg}^{-1}$ by abscission date (Fig. 2).

\section{Appropriate leaf sampling period}

Application of mathematical derivatives allowed the identification of periods during which nutrient concentrations were stable, i.e., when derivatives were closest to zero. For the winter flush, this period occurred when leaf age was 173 to 237 DABB (10 Aug. to 13 Oct.) (Fig. 3A) and 198 to 237 DABB (4 Sept. to 13 Oct.) (Fig. 3B), respectively, for macro- and micronutrients. These periods partially coincided with the time when winter leaves reached their maximum length (226 DABB; Table 2; Fig. 3). In the case of the summer flush, the stable period for macronutrients occurred when leaves were 107 to 148 DABB (25 Nov. to 5 Jan.) (Fig. 4A) and 117 to 160 DABB (5 Dec. to 17 Jan.) for micronutrients, with the exception of Mn, whose concentration did not show a leveling off period (Fig. 4B). These stable periods ended 15 to $27 \mathrm{~d}$ before summer leaves reached their maximum length.

After placing together the periods of stable nutrient concentrations, it was possible to identify common sampling periods for both macro- and micronutrients. This allowed the identification of the appropriate leaf sampling period for each vegetative flush (Table 3). For winter leaves it was from 4 


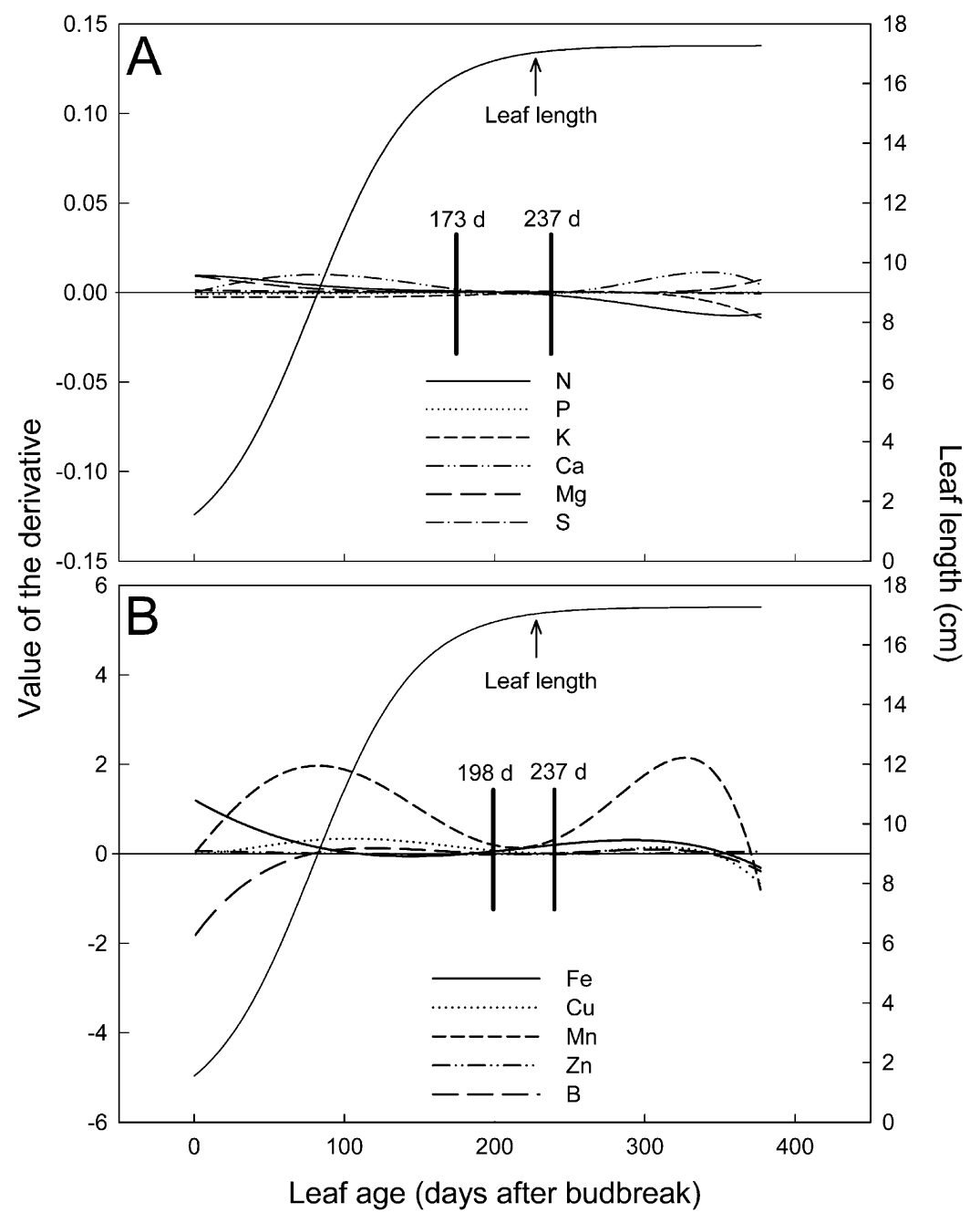

Fig. 3. Leaf length, values of the mathematical derivatives of the mathematical functions, and period of nutrient stability (delimited by vertical lines) for macro- (A) and micronutrient (B) concentrations in leaves of the winter vegetative flush of 'Hass' avocado. Budbreak: 19 Feb. 2004. Arrows point to the date when leaf growth ceased $(P=0.01)$.

Table 2. Seasonal growth (blade length) of leaves from winter and summer vegetative flushes and major phenological events of 'Hass' avocado in Nayarit, Mexico. ${ }^{z}$

\begin{tabular}{|c|c|c|c|}
\hline \multirow[b]{2}{*}{ Sampling date } & \multicolumn{2}{|c|}{ Days after budbreak ${ }^{y}$} & \multirow[b]{2}{*}{ Major phenophases ${ }^{x}$} \\
\hline & $\begin{array}{l}\text { Winter } \\
\text { leaves }\end{array}$ & $\begin{array}{l}\text { Summer } \\
\text { leaves }\end{array}$ & \\
\hline Feb. 2004 & & & Bloom, fruit set, winter vegetative flush \\
\hline April & 43 & - & Fruit in S-I and S-II, summer leaves abscission \\
\hline May & 73 & - & Fruit in S-I and S-II \\
\hline June & 104 & - & Fruit in S-II \\
\hline July & 134 & - & $\begin{array}{l}\text { Fruit in S-II, fruit drop, root growth, summer } \\
\text { vegetative flush }\end{array}$ \\
\hline August & 165 & - & Fruit in S-III, root growth, summer vegetative flush \\
\hline September & 196 & 31 & Fruit in S-III \\
\hline October & $226^{\mathrm{w}}$ & 62 & Harvest, commitment to flowering \\
\hline November & 257 & 93 & Floral initiation \\
\hline December & 287 & 123 & Inflorescence at cauliflower stage \\
\hline Jan. 2005 & 318 & 144 & Inflorescence elongation \\
\hline February & 349 & $175^{\mathrm{w}}$ & Bloom, fruit set, winter vegetative flush \\
\hline March & 377 & 215 & Fruit set, fruit in S-I, winter leaves abscission \\
\hline April & - & 235 & Fruit in S-I and S-II, summer leaves abscission \\
\hline
\end{tabular}

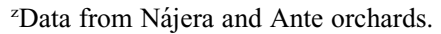

${ }^{y}$ Budbreak dates: Winter: 19 Feb. 2004; Summer: 11 Aug. 2004.

${ }^{\mathrm{x}}$ Cossio-Vargas et al. (2008).

${ }^{\text {w }}$ Starting at this sampling dates, full leaf length had been attained (Waller-Duncan, $P=0.01$ ).

Sept. to 13 Oct., when leaves were 197 to 236 DABB (6.6 to 7.9 months old). For summer leaves, except $\mathrm{Mn}$, the appropriate sampling period was from 5 Dec. to 5 Jan., which correspond to 116 to $147 \mathrm{DABB}$ (3.9 to 4.9 months old) (Table 3).

\section{Discussion}

Winter and summer leaves lived 12.5 and 7.8 months, respectively. This agreed with the 12 months mentioned by Salazar-García et al. (2007b) for winter leaves but differed with the 9 months mentioned by the same author for summer leaves. The elapsed time from leaf emergence to full leaf length was longer for winter flush leaves (226 d) than for the summer (175 d) (Table 2). However, the proportional lifetime spent to reach their maximum length was greater for summer $(74.5 \%)$ than for winter leaves $(59.9 \%)$.

The fact that summer leaves were larger $(19 \mathrm{~cm})$ than winter leaves $(17.3 \mathrm{~cm})(P=$ 0.0001 ) could be the result of the presence of warmer temperatures, rainfall, and reduced sunlight during the summer in the area of study (Cossio-Vargas et al., 2008). Nevertheless, Wolstenholme and Whiley (1999) mentioned that summer leaves grow larger as an adaptation to the presence of clouds and low luminous intensity.

Changes in N, P, S, Fe, Cu, Mn, Zn, and B concentrations during the leaf growth cycle were different for winter and summer leaves. However, the concentration patterns for $\mathrm{K}$, $\mathrm{Ca}$, and $\mathrm{Mg}$ were similar between both types of leaves. Soil pH and fertility were very similar for both orchards studied and frequent for avocado orchards in Mexico (SalazarGarcía, 2002); therefore, variation in the pattern of changes of nutrient concentrations could be related to the season when the leaves were born and their exposure to different environmental conditions as well as to soil fertilization (done in July to September) and soil moisture, which makes different soil nutrients available in relation to the tree's demand. In the region where this study was performed, most 'Hass' avocado are grown under rainfed conditions and emergence of winter leaves takes place during the cool and dry season, whereas summer vegetative growth occurs in the hot and rainy season (Cossio-Vargas et al., 2008).

Tree phenology was an additional factor in leaf nutrient accumulation. A decline in the concentration of some nutrients coincided with some key phenological events (Table 2; Figs. 1 and 2). In winter leaves, $\mathrm{N}$ concentration decreased at fruit maturity and harvest (226 DABB, October). A similar decline was observed for $\mathrm{S}$ and $\mathrm{K}$ at $\approx 300$ and $315 \mathrm{DABB}$, respectively (January; inflorescence elongation); for B, the drop started at 347 DABB (February; bloom, fruit set, winter vegetative flush). In the case of summer leaves, $K$ and $B$ concentrations started to decline at inflorescence elongation (140 DABB, January), whereas $\mathrm{N}, \mathrm{S}, \mathrm{Fe}, \mathrm{Cu}$, and $\mathrm{Mn}$ showed the same response at bloom (155 to $170 \mathrm{DABB}$, February). Zn was another nutrient whose concentration decreased at fruit set and Stage I of fruit growth (197 DABB, March). The described responses seem to be normal for 'Hass' avocado under rainfed conditions as a result of the intense nutrient demand caused by a single flowering period and one harvest per year (Salazar-García et al., 2007a). 


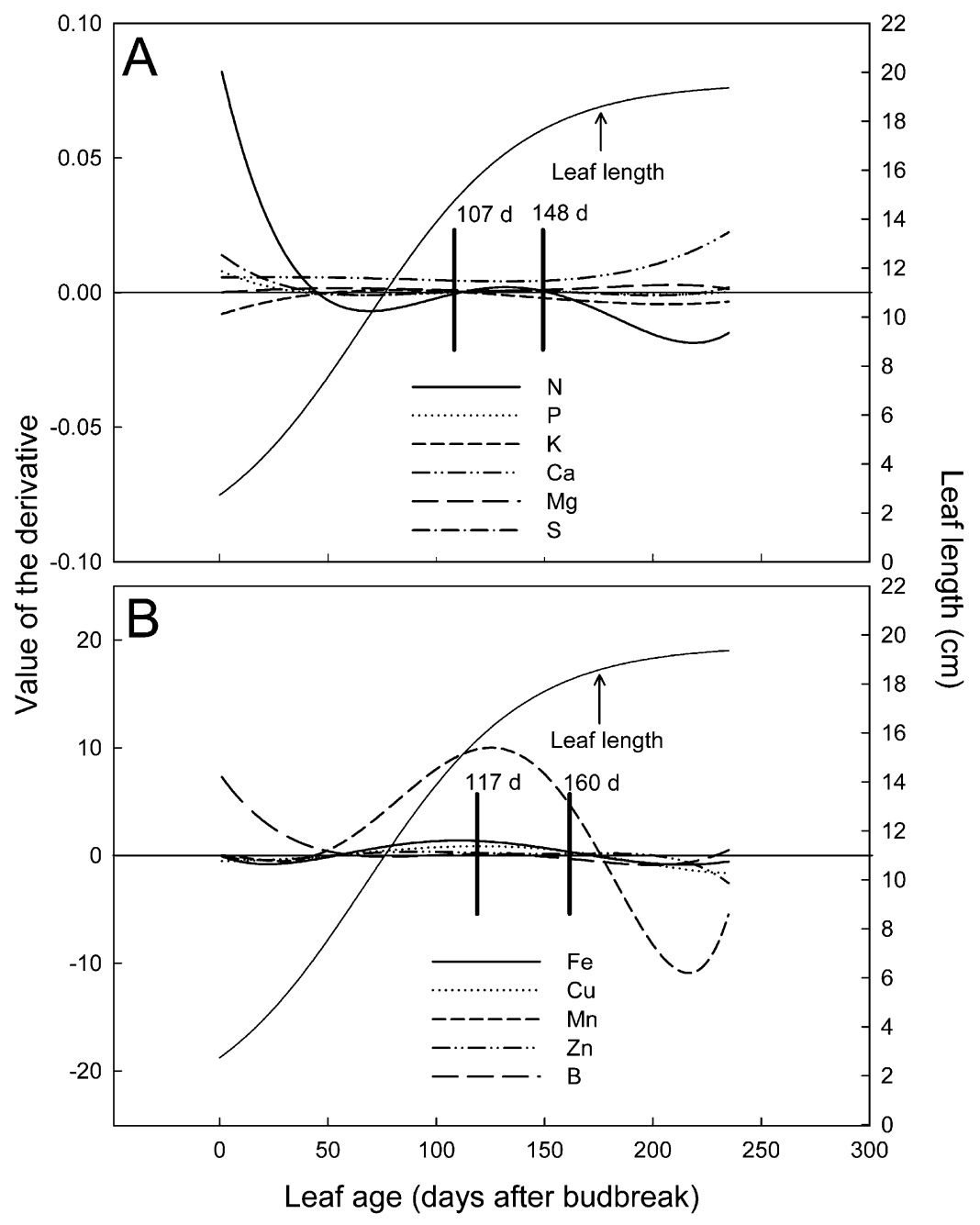

Fig. 4. Leaf length, values of the mathematical derivatives of the mathematical functions, and period of nutrient stability (delimited by vertical lines) for macro- (A) and micronutrient (B) concentrations in leaves of the summer vegetative flush of 'Hass' avocado. Budbreak: 11 Aug. 2004. Arrows point to the date when leaf growth ceased $(P=0.01)$.

Table 3. Periods of nutrient stability (shadowed cells) and appropriate dates for leaf sampling (delimited by thicker vertical lines) in winter and summer flush leaves of 'Hass' avocado in Nayarit, Mexico. ${ }^{2}$

\begin{tabular}{|c|c|c|c|c|c|}
\hline & \multicolumn{5}{|c|}{ Winter leaves } \\
\hline & July & August & September & October & November \\
\hline Macronutrients & & & $4^{\text {th }}$ & $13^{\text {th }}$ & \\
\hline Micronutrients & & & & & \\
\hline
\end{tabular}

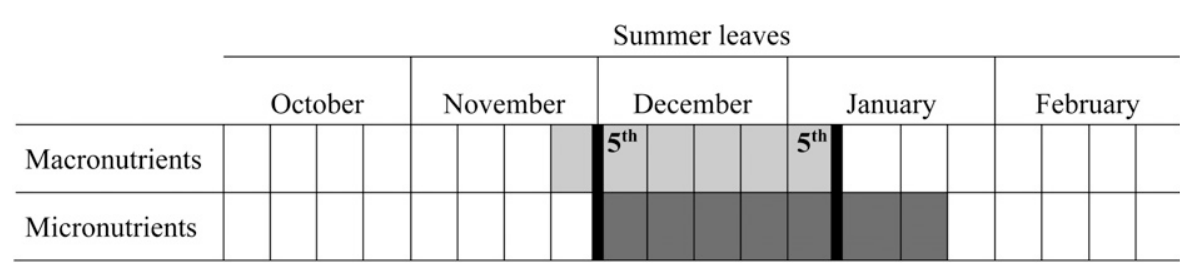

The decrease in the concentration of some nutrients during the period when leaves attained maturity and the time when they were shed was significant. Killingbeck (1986) defined this process as resorption and it allows growth to be partly independent of external nutrient availability at the beginning of the growing season and occurs even when nutrient availability is low (Cherbuy et al., 2001; Colin-Belgrand et al., 1996; Nambiar and Fife, 1991). In the present study, nutrient resorption differed between types of leaves, being more widespread in summer $(\mathrm{N}, \mathrm{P}, \mathrm{K}, \mathrm{S}, \mathrm{Cu}, \mathrm{Mn}, \mathrm{Zn}$, and $\mathrm{B})$ than in winter leaves $(\mathrm{N}, \mathrm{P}, \mathrm{K}, \mathrm{S}$, and $\mathrm{Fe})$. With the except for $\mathrm{Cu}$ in winter leaves and $\mathrm{Fe}$ in summer leaves, these results are consistent with the results of Salazar-García et al. (2007b).

An obvious overlap between winter and summer leaves was observed in the present study (Figs. 1 and 2). In general, the role of winter leaves appears to be the support of fruit growth and development throughout maturity as well as the initial growth of the summer vegetative flush. The major role of summer leaves is likely to sustain the floral development, fruit set, and Stages I and II of fruit growth (Table 2). Similar physiological overlapping has been mentioned for mango leaves from different flushes (Castro-López et al., 2012).

Our research demonstrated that for the 'Hass' avocado in Nayarit, the appropriate sampling period for leaves of the winter vegetative flush was when they were 6.6 to 7.9 months old (4 Sept. to 13 Oct.). This information partially validated the 6 to 7 months proposed by Salazar-García (2002) for leaves of this flush in Nayarit and displaced almost by 1 month the adequate time for leaf sampling. The present results to some extent agree with suggestions for leaves of the spring flush in California (5 to 7 months; August to October) (Crowley et al., 1993), New Zealand (4 to 7 months; August to November, northern hemisphere) (Dixon et al., 2007), and Michoacán (5 to 7 months; April to June) (Maldonado-Torres et al., 2007).

For summer flush leaves, the adequate sampling period was shorter than for those of the winter flush and occurred when leaves were 3.9 to 4.9 months ( 5 Dec. to 5 Jan.). No available literature was found on optimal sampling time for summer leaves.

Most studies carried out to identify the optimal dates for leaf sampling in several avocado cultivars suggest plotting leaf nutrient concentrations to visually determine the period of stability for both macro- and micronutrients (Bingham, 1961; Bould, 1966; Embleton et al., 1958; Embleton and Jones, 1966; Koen and du Plessis, 1992; Koo and Young, 1977; Lahav et al., 1990; Oppenheimer et al., 1961; Ulrich, 1976). The mathematical procedure used in the present study was useful to determine the appropriate period to conduct leaf sampling for analyses of most nutrients in 'Hass' avocado in Nayarit and could be useful to test both the procedure and the leaf sampling timing in other avocado producing regions.

\section{Literature Cited}

Bingham, F.T. 1961. Seasonal trends in nutrient composition of Hass avocado leaves. Proc. Amer. Soc. Hort. Sci. 78:149-160.

Bould, C. 1966. Leaf analysis of deciduous fruits, p. 651-684. In: Childers, N.F. (ed.). Temperate to tropical fruit nutrition. Horticultural Publications. Rutgers Univ., New Brunswick, NJ.

Castro-López, M.G., S. Salazar-García, I.J.L. González-Durán, R. Medina-Torres, and J. González-Valdivia. 2012. Evolución nutrimental foliar en tres cultivares de mango en Nayarit, 
México (Foliar nutrient evolution in three mango cultivars in Nayarit, Mexico). Rev. Mex. Cienc. Agríc. 3:685-700 [in Spanish and English].

Cherbuy, B., R. Joffre, D. Gillon, and S. Rambal. 2001. Internal remobilization of carbohydrates, lipids, nitrogen and phosphorus in the Mediterranean evergreen oak Quercus ilex. Tree Physiol. 21:9-17.

Colin-Belgrand, M., J. Ranger, and J. Bouchon. 1996. Internal nutrient translocation in chestnut tree stemwood. III. Dynamics across an age series of Castanea sativa (Miller). Ann. Bot. (Lond.) 78:729-740.

Cossio-Vargas, L.E., S. Salazar-García, I.J.L. González-Durán, and R. Medina-Torres. 2008. Fenología del aguacate 'Hass' en el clima semicálido de Nayarit, México. Rev. Chapingo Ser. Hort. 14:153-159.

Crowley, D.E., S. Woody, B. Faber, and M.L. Arpaia. 1993. Zinc nutrition in avocado. Calif. Avo Soc. Yrbk. 77:95-100.

Dixon, J., T.A. Elmsly, and E.M. Dixon. 2007. Seasonal variations in leaf mineral content. New Zealand Avocado Growers Assn. Ann. Res. Rpt. 6:21-34.

Draper, N.R. and H. Smith. 1981. Applied regression analysis. 2nd Ed. John Wiley \& Sons, Inc., New York, NY.

Embleton, T.W. and W.W. Jones. 1966. Avocado and mango nutrition, p. 51-76. In: Childers, N.F. (ed.). Fruit nutrition. Horticultural Publications, Rutgers Univ., New Brunswick, NJ.

Embleton, T.W., W.W. Jones, J.D. Kirkpatrick, and D. Gregory-Allen. 1958. Influence of sampling date, season and fertilization on macronutrients in avocado Fuerte leaves. Proc. Amer. Soc. Hort. Sci. 72:309-320.

García-Amaro, E. 1988. Comisión nacional para el conocimiento y uso de la biodiversidad (CONABIO). 'Climas' (clasificación de Köppen, modificado por García). Escala 1:1000 000 México. Shapefile online. July 2012. <http:// www.conabio.gob.mx/informacion/metadata/ gis/clima1mgw.xml?_httpcache=yes\&_xsl=/db/ metadata/xsl/fgdc_html.xsl\&_indent $=$ no $>$.

Granville, W.A., P.F. Smith, and W.R. Longley. 1963. Elements of the differential and integral calculus. 2nd Ed. John Wiley \& Sons Inc., Hoboken, NJ.

INEGI. 1999. Carta Edafológica del estado de Nayarit. Dirección General de Geografía del Instituto Nacional de Estadística Geografía e Informática (INEGI). 2nd. Ed. Escala 1:50 000. Aguascalientes, Ags., México.

Killingbeck, K.T. 1986. The terminological jungle revisited: Making a case for use of the term resorption. Oikos 46:263-264.

Koen, T.J. and S.F. du Plessis. 1992. Optimal leaf analysis norms for avocado (cv. Fuerte). Proc. Second World Avocado Congress, Orange, CA, 21-26 Apr. 1991. 1:289-299.

Koo, R.C.J. and T.W. Young. 1977. Effect of age position and fruiting status on mineral composition of Tonnage avocado leaves. J. Amer. Soc. Hort. Sci. 102:311-313.

Lahav, E., Y. Bar, and D. Kalmar. 1990. Effect of nitrogenous fertilization on the annual variations in nutrient in avocado leaves. Commun. Soil Sci. Plant Anal. 21:1353-1365.

Liu, X., R. Hofshi, and M.L. Arpaia. 1999. 'Hass' avocado leaf growth, abscission, carbon production and fruit set, p. 52-55. In: Arpaia, M.L. and R. Hofshi (eds.). Proc. Avocado Brainstorming. Session 3. Canopy Management, Riverside, CA, 27-28 Oct.

Maldonado-Torres, R., M.E. Álvarez-Sánchez, G. Almaguer-Vargas, A.F. Barrientos-Priego, and R. García-Mateos. 2007. Estándares nutrimentales para aguacatero 'Hass'. Rev. Chapingo Ser. Hortic. 13:103-108.

Minitab Inc. 1996. Minitab for Windows, Release 11.2. State College, PA.

Nambiar, E.K. and D.N. Fife. 1991. Nutrient retranslocation in temperate conifers. Tree Physiol. 9:185-207.

Neter, J., W. William, and H.K. Michael. 1985. Applied linear statistical models. 2nd Ed. Homewood, IL.

Oppenheimer, Ch., A. Kadman, and F. Radziszewska. 1961. Some observations on the nutritional status of avocado trees in Israel. Calif. Avocado Soc. Yrbk. 45:81-86.

Roets, N.J.R., S. De Meillon, C. Kaiser, P.J. Robbertse, R. Owen, and R. Ehlers. 2006. Possible causes and measures to prevent exces- sive leaf abscission in the avocado (Persea americana Mill.) cultivar Ryan. South African Avocado Growers' Assn. Yrbk. 29:21-36.

Salazar-García, S. 2002. Nutrición del Aguacate, Principios y Aplicaciones. Instituto Nacional de Investigaciones Forestales, Agrícolas y Pecuarias e Instituto de la Potasa y el Fósforo, Querétaro, México.

Salazar-García, S., L.E. Cossio-Vargas, I.J.L. González-Durán, and C.J. Lovatt. 2007a. Desarrollo floral del aguacate 'Hass' en clima semicálido. Parte I. Influencia de la carga del fruto y edad de los brotes. Rev. Chapingo Ser. Hortic. 13:87-92.

Salazar-García, S., L.E. Cossio-Vargas, and I.J.L. González-Durán. 2007b. Reciclamiento de nutrimentos por las hojas de aguacate 'Hass' (Nutrient recycling by 'Hass' avocado leaves). VI World Avocado Congr., Viña Del Mar, Chile, 12-16 Nov. 2007. Proc. 3a-102.

Salazar-García, S., L.E. Cossio-Vargas, and J.L. González-Durán. 2009. La fertilización de sitio específico mejoró la productividad del aguacate 'Hass' en huertos sin riego. Agric. Téc. Méx. 35:439-448.

Salazar-García, S. and I. Lazcano-Ferrat. 2003. Site specific fertilization increased yield and fruit size in 'Hass' avocado. Better Crops Intl. 17:12-15.

SAS. 2009. SAS 9.2 procedures guide. SAS Institute Inc., Cary, NC.

SigmaPlot. 2006. SigmaPlot for Windows. Version 10.0. Systat Software Inc., Chicago, IL.

Ulrich, A. 1976. Plant tissue analysis. Plant analysis as a guide in fertilizing crops, p. 1-4. In: Reisenauer, H.M. (ed.). Soil and plant-tissue testing in California. Division of Agricultural Sciences, University of California, Riverside, CA.

Whiley, A.W. and B. Schaffer. 1994. Avocado, p. 3-35. In: Schaffer, B. and P.C. Andersen (eds.). CRC handbook of environmental physiology of fruit crops. Vol. I. Subtropical and tropical crops. CRC Press Inc., Boca Raton, FL.

Wolstenholme, B.N. and A.W. Whiley. 1999. Ecophysiology of the avocado (Persea americana Mill.) tree as a basis for pre-harvest management. Rev. Chapingo Ser. Hortic. 5:77-88. 